\title{
Natural Killer-Like T-Cell Lymphoma Localized to the Terminal lleum: Case Report
}

\author{
Ümit BAYOL', Süheyla CUMURCU', Kerem KARAMAN², Cem TUĞMEN², Çağlar AKDENiZ', \\ Özlem AKMAN', Saime ÜNLÜOĞLU'
}

Departments of ${ }^{1}$ Pathology and ${ }^{2}$ General Surgery, Tepecik Training and Research Hospital, IZMIR, TURKEY

\begin{abstract}
Intestinal intraepithelial lymphocytes are non-organized lymphoid populations that are composed of heterogeneous subsets with diverse ontogeny and phenotypes, and the differential diagnosis is crucial. A 43-year-old male patient underwent an emergency laparotomy due to a perforated mass of the terminal ileum. A right hemicolectomy plus small bowel resection was performed. Histopathological examination showed medium to large cells with vesicular nuclei, including marked nucleoli with large, colorless cytoplasm. No signs of celiac disease were found in the adjacent mucosa. The tumor cells were immunohistochemically CD45+, CD3+, CD4+, CD8+, CD56+, Pan-Cytokeratin-, CD20-, CD79a-, CD5- and CD30-. Endomysial antibody and antigliadin antibody, IgM and IgG tests; and anti-Ebstein Barr virus latent membrane protein all proved negative. Finally, the histopathological diagnosis of tumor mass was natural killer-like T-cell lymphoma. Primary intestinal cytotoxic natural killer-like T-cell lymphoma is a rare entity, which is difficult to distinguish from other T-cell lymphomas. In addition to microscopic evaluation, immunohistochemical analysis and serological tests are essential to reach a definitive diagnosis.
\end{abstract}

Key Words: Natural killer T-cells, Lymphoma, Celiac disease

\section{INTRODUCTION}

Gastrointestinal non-Hodgkin's lymphomas (NHL) are the most common type of primary extranodal lymphomas with the majority being of B-cell lineage (1). In contrast to their B-cell counterparts, primary intestinal natural killer and T-cell lymphomas (PINKTL) are very rare and generally more aggressive with various subtypes, and the 5 -year survival is usually less than $10 \%$ (1-3). Intestinal intraepithelial lymphocytes make up one of the largest non-organized lymphoid populations (4). They consist of heterogeneous subsets including T-cells or natural killer (NK) cells and neoplastic counterparts of each with diverse ontogeny and phenotype. Additionally, there are systemic T-cell or NK cell lymphomas [such as $\gamma \delta$ T cell lymphoma and extranodal natural killer-like T-cell lymphoma (NK/Tcell lymphoma), nasal type] that may involve the intestine and the differential diagnosis is crucial (5-12). We report a case with a perforated mass of the terminal ileum diagnosed as NK/T-cell lymphoma.

\section{CASE REPORT}

A 43-year-old male patient was admitted to the emergency clinic with complaints of abdominal pain, nausea and vomiting. His physical exam revealed generalized peritonitis with rebound tenderness. A giant mass $(>20 \mathrm{~cm})$ originating

(Turk Patoloji Derg 2016, 32:40-43)

Received : 07.02.2012 Accepted : 16.04.2012 from the small bowel and filling the lower abdominal cavity was detected by abdominal computerized tomography (Figure 1). The patient underwent an emergency laparotomy due to suspicion of perforation. During the operation, a perforated mass of the terminal ileum, which had invaded the cecum and other parts of the small bowel, was found. A right hemicolectomy plus small bowel resection was performed and the restoration of the gastrointestinal tract was provided with an ileo-colonic anastomosis. A second exploration was performed on the fifth postoperative day for anastomotic leakage after detecting intestinal content in drains. An end ileostomy plus Hartman's procedure was performed and the abdominal cavity was irrigated and cleaned with saline before abdominal closure. No complication developed in the postoperative period and the patient was discharged on the $15^{\text {th }}$ postoperative day.

Histopathological examination of the resected ileal mass revealed T-cell lymphoma. Microscopically, medium to large sized cells with vesicular nuclei including marked nucleoli with large, colorless cytoplasm were seen. No signs of celiac disease were found in the adjacent mucosa. The tumor cells were immunuhistochemically positive with $\mathrm{CD} 45, \mathrm{CD} 3, \mathrm{CD} 4, \mathrm{CD} 8, \mathrm{CD} 56$ and negative with pan-cytokeratin (panCK), CD20, CD79a, CD5 and CD30 (Figure 2A-D). After a careful anamnesis, no history or

Correspondence: Kerem KARAMAN

Tepecik Eğitim ve Araştırma Hastanesi, 3. Cerrahi Kliniği,

Yenișehir, 35170, İZMİR, TURKEY

E-mail: karaman_kerem@yahoo.com.tr Phone: +90 2644445400 


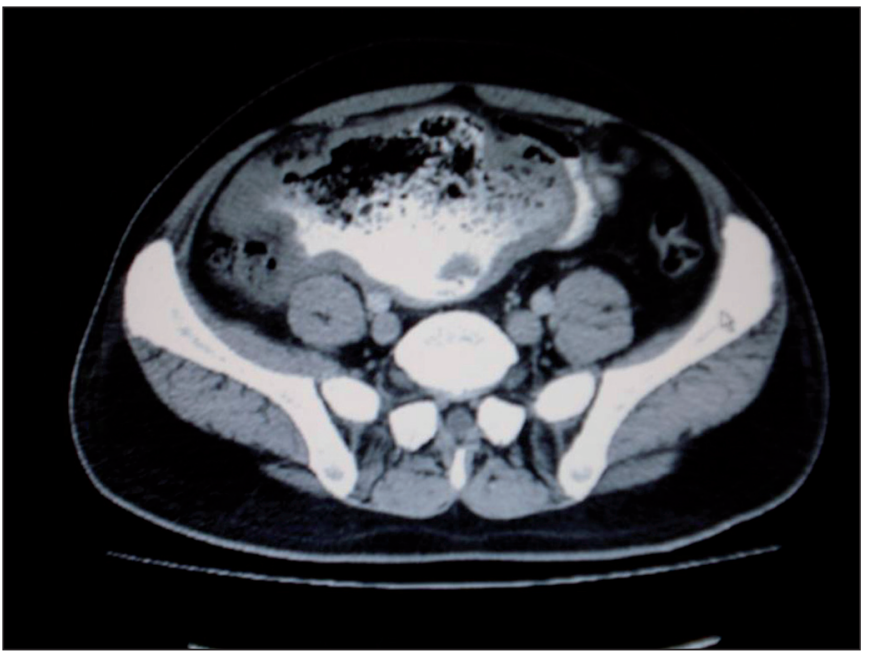

Figure 1: Abdominal computerized tomography demonstrates the giant mass, which filled the lower abdominal cavity. association with celiac disease was determined and the endomysial antibody and antigliadin antibody IgM and IgG tests were negative. Ebstein-Barr virus (EBV) antibodies IgM and IgG were positive for EBV viral capsid antigen (VCA) and EBV virus nuclear antigen (EBNA). However, no additional tumor was detected by screening in the nasopharynx, skin and soft tissues or other parts of the gastrointestinal tract. Further, immunohistochemically, anti-EBV latent membrane protein (anti EBV-LMP; Daco, Denmark) was also negative. Hence, the histopathological diagnosis of the tumoral mass was NK/T-cell lymphoma, and the patient was referred to medical oncology where he was placed on a Hyper-CVAD (cyclophosphamide, vincristine, doxorubicin, dexamethasone) chemotherapy regimen. At the end of the six-month follow-up, the patient is now symptomless and is coming for routine check- ups.
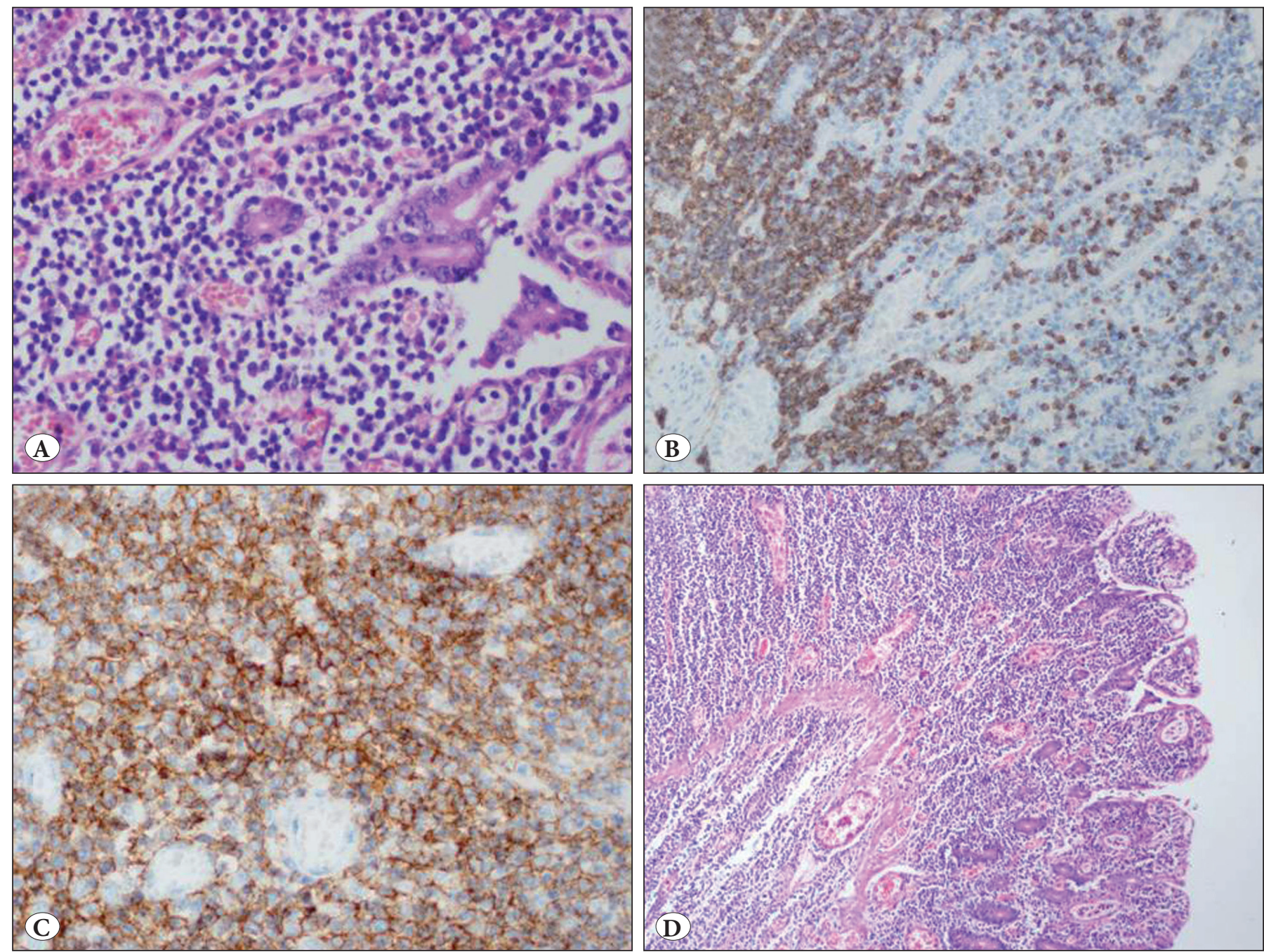

Figure 2: A) İnfiltration of the mucosa by tumor cells (H\&E; x200). B) CD3+ tumor cells infiltrating the mucosa (CD3; x100). C) CD56+ tumor cells (CD56; x200). D) Transmural infiltration of the bowel wall by neoplastic cells (H\&E; x40). 


\section{DISCUSSION}

Primary intestinal natural killer and T-cell lymphomas (PINKTL) comprise three different entities: enteropathyassociated T-cell lymphoma (EATL), peripheral T-cell lymphoma (PTCL) and NK cell lymphoma. According to the World Health Organization classification (WHO, 2008), EATL is defined as an intestinal tumor derived from intraepithelial lymphocytes. Adjacent to these lesions, villous atrophy and crypt hyperplasia exists in the non-neoplastic small intestinal mucosa $(13,14)$. EATL is frequently localized in the proximal small intestine. In contrast to celiac disease (male/female ratio: $1 / 2$ ), men are more affected (64\%) in EATL. The mean age at diagnosis is approximately 64 years (15). Outcome is very poor with a 2-year survival rate of $15-20 \%$ (16-18). Based on morphology, genetic profile and immunohistochemistry, EATL can be divided into two groups. EATL type I has strong association with celiac disease and presents often with malabsorption, weight loss and celiac disease related symptoms. However, EATL type II is not associated with celiac disease, and is presented usually with small bowel obstruction or perforation (19). EATL type II comprises $10-20 \%$ of all EATL in Western countries. Although EATL is very rare in the Far East, EATL type II has been reported from Asian countries including Taiwan and Japan $(19,20)$. EATL type I cells are CD3+, CD5-, CD7+, CD8+/-, CD4-, CD56-, CD103+, TCR-beta +/-. The majority of the tumor cells are $\mathrm{CD} 30+$. On the other hand, EATL type II cells are $\mathrm{CD} 3+, \mathrm{CD} 4-, \mathrm{CD} 8+, \mathrm{CD} 56+$, TCR- $\beta+$. Interestingly, CD30 is often negative. Since CD8 and CD56 are critically important in diagnosing EATL type II, these markers should be included in the standard immunological work-up when lymphoma has been diagnosed (14). The NK cells are CD3-, CD7+, CD56+/- and CD57- (21). Primary intestinal cytotoxic NK/T-cell lymphoma should be considered as a distinct entity. These tumors consist of monomorphic small or medium tumor cells that express CD3, CD8 and CD56 without in association with celiac disease $(1,9,22)$. The Revised European American Lymphoma Classification (REAL) system has not accurately defined the phenotype of the tumor cells. It is also difficult to classify NK/T-cell lymphoma. Further, CD56 is not described in intestinal T cell lymphoma by the REAL classification system (2325). NK/T-cell lymphoma is differentiated from EATL type II by lacking enteropathy and occurring in colon [1]. Our patient displayed CD3+, CD4+, CD5-, CD8+, CD56+, CD30-. Histopathologically, we found no signs of enteropathy in the adjacent tissue during microscopic evaluation and anamnesis revealed any history of celiac disease. Furthermore, antigliadin antibody IgM and IgG serology and endomysial antibody tests were also negative. The nasal type of the extranodal NK/T-cell lymphoma occurs usually in the nasopharyngeal region; it is CD56 positive CD8 negative, lacks usually $\mathrm{T}$ cell receptor (TCR) gene rearrangement, and is strongly associated with EBV $(1,25-27)$. It is described as "NK/T "rather than "NK" because of some reported cases in which cytotoxic T-cell phenotype was observed $(1,14)$. Although, the present case had positive IgM and IgG antibodies for EBV VCA and EBNA, a diagnosis of a nasal type NK cell lymphoma is eliminated due to absence of nasopharyngeal involvement by the tumor. Additionally, the anti EBV-LMP in the tumor cells was negative. Thus, our case was diagnosed as NK/Tcell lymphoma.

$\mathrm{NK} / \mathrm{T}$-cell lymphoma of the terminal ileum is a rare entity that has similar endoscopic features of inflammatory bowel disease, and often invades serosa. Patients usually present at an advanced stage with peritonitis as a result of tumor perforation (24). NK/T-cell lymphomas are reported in a few studies as case series and the true incidence is probably more frequent than expected $(26,27)$. Furthermore, NK/Tcell lymphoma of the terminal ileum can mimic Behçet's enteritis or intestinal tuberculosis and should be considered in the differential diagnosis of these diseases. The true diagnosis can only be established by histopathological evaluation $(28,29)$.

In conclusion, primary intestinal cytotoxic natural killerlike T-cell lymphoma is a rare entity, which is difficult to distinguish from other T-cell lymphomas. In addition to microscopic evaluation immunohistochemical analysis and serological tests are needed to reach a definitive diagnosis.

\section{REFERENCES}

1. Chuang SS, Chang ST, Chuang WY, Huang WT, Hsieh PP, Tsou MH, Liao YL, Lin SH, Hsieh YC, Lu CL, Sheu MJ, Liu H. NK-cell lineage predicts poor survival in primary intestinal NK-cell and T-cell lymphomas. Am J Surg Pathol. 2009;33:1230-40.

2. Isaacson PG, Du MQ. Gastrointestinal lymphoma: Where morphology meets molecular biology. J Pathol. 2005;205:255-74.

3. Nakamura S, Matsumoto T, Takeshita M, Kurahara K, Yao T, Tsuneyoshi M, Iida M, Fujishima M. A clinicopathologic study of primary small intestine lymphoma: Prognostic significance of mucosa-associated lymphoid tissue-derived lymphoma. Cancer. 2000;88:286-94.

4. Asano N, Suzuki R, Kagami Y, Ishida F, Kitamura K, Fukutani H, Morishima Y, Takeuchi K, Nakamura S. Clinicopathologic and prognostic significance of cytotoxic molecule expression in nodal peripheral T-cell lymphoma, unspecified. Am J Surg Pathol. 2005;29:1284-93. 
5. Roschewski M, Wilson WH. Biology and management of rare primary extranodal T-cell lymphomas. Oncology (Williston Park). 2010;24:94-100.

6. Ghimire P, Wu GY, Zhu L. Primary gastrointestinal lymphoma. World J Gastroenterol. 2011;17:697-707.

7. Chott A, Haedicke W, Mosberger I, Födinger M, Winkler K, Mannhalter C, Müller-Hermelink HK. Most CD56+ intestinal lymphomas are CD8+CD5-T-cell lymphomas of monomorphic small to medium size histology. Am J Pathol. 1998;153:1483-90.

8. Franc MC, Bono E, Sun T. An unusual case of peripheral T-cell lymphoma with CD56 positivity and angiocentric, angiodestructive morphology arising in the ileum. Arch Pathol Lab Med. 2005;129:527-30.

9. Muram-Zborovski T, Loeb D, Sun T. Primary intestinal intraepithelial natural killer-like T-cell lymphoma: Case report of a distinct clinicopathologic entity. Arch Pathol Lab Med. 2009;133:133-7.

10. Chan JKC, Jaffe ES, Ralfkiaer E. Extranodal NK/T-cell lymphoma, nasal type. In: Jaffe ES, Harris NL, Stein H, Vardiman JW, editors. World Health Organization Classification of Tumours: Pathology and Genetics of Tumours of Haematopoietic and Lymphoid Tissues. Lyon: IARC Press; 2001. 204-7.

11. Macon WR. Peripheral T-cell lymphomas. Hematol Oncol Clin North Am. 2009;23:829-42.

12. Burke JS. Lymphoproliferative disorders of the gastrointestinal tract: A review and pragmatic guide to diagnosis. Arch Pathol Lab Med. 2011;135:1283-97.

13. Garcia-Herrera A, Song JY, Chuang SS, Villamor N, Colomo L, Pittaluga S, Alvaro T, Rozman M, de Anda Gonzalez J, Arrunategui AM, Fernandez E, Gonzalvo E, Estrach T, Colomer D, Raffeld M, Gaulard P, Campo E, Jaffe ES, Martinez A. Nonhepatosplenic $\gamma \delta$ T-cell lymphomas represent a spectrum of aggressive cytotoxic T-cell lymphomas with a mainly extranodal presentation. Am J Surg Pathol. 2011;35:1214-25.

14. Isaacson P, Chott A, Ott G, Stein H. Enteropathy-associated T-cell lymphoma. In: Swerdlow SH, Campo E, Harris NL, Jaffe ES, Pileri SA, Thiele J, Vardiman, JW. editors. WHO classification of tumours of haemotopoietic and lymphoid tissue. 4th ed. Lyon: IARC Press; 2008. 289-91.

15. Verbeek WH, Van De Water JM, Al-Toma A, Oudejans JJ, Mulder CJ, Coupé VM. Incidence of enteropathy-associated T-cell lymphoma: A nation-wide study of a population-based registry in The Netherlands. Scand J Gastroenterol. 2008;43:1322-8.

16. Sieniawski MK, Lennard AL. Enteropathy-associated T-cell lymphoma: Epidemiology, clinical features, and current treatment strategies. Curr Hematol Malig Rep. 2011;6:231-40.

17. Al-Toma A, Verbeek WH, Hadithi M, von Blomberg BM, Mulder CJ. Survival in refractory coeliac disease and enteropathyassociated T-cell lymphoma: Retrospective evaluation of singlecentre experience. Gut. 2007;56:1373-8.
18. van de Water JM, Cillessen SA, Visser OJ, Verbeek WH, Meijer CJ, Mulder CJ. Enteropathy associated T-cell lymphoma and its precursor lesions. Best Pract Res Clin Gastroenterol. 2010;24:4356.

19. Chuang SS, Liao YL, Liu H, Lin SH, Hsieh PP, Huang WT, Chen HK, Isaacson PG. The phenotype of intraepithelial lymphocytes in Taiwanese enteropathy-associated T-cell lymphoma is distinct from that of the West. Histopathology. 2008;53:234-6.

20. Akiyama T, Okino T, Konishi H, Wani Y, Notohara K, Tsukayama C, Tsunoda T, Tasaka T, Masaki Y, Sugihara T, Sadahira Y. CD8+, CD56+ (natural killer-like) T-cell lymphoma involving the small intestine with no evidence of enteropathy: Clinicopathology and molecular study of five Japanese patients Pathol Int. 2008;58:62634.

21. Eiras P, Leon F, Camarero C, Lombardia M, Roldan E, Bootello A, Roy G. Intestinal intraepithelial lymphocytes contain a CD3$\mathrm{CD} 7+$ subset expressing natural killer markers and a singular pattern of adhesion molecules. Scand J Immunol. 2000;52:1-6.

22. Yuan CM, Stein S, Glick JH, Wasik MA. Natural killer-like T-cell lymphoma of the small intestine with a distinct immunophenotype and lack of association with gluten-sensitive enteropathy. Arch Pathol Lab Med. 2003;127:142-6.

23. Tung CL, Hsieh PP, Chang JH, Chen RS, Chen YJ, Wang JS: Intestinal T-cell and natural killer-cell lymphomas in Taiwan with special emphasis on 2 distinct cellular types: Natural killer-like cytotoxic T cell and true natural killer cell. Hum Pathol 2008;39: 1018-25.

24. Deguchi Y, Yoshimatsu K, Endo S: Natural killer-like T cell lymphoma of the small intestine: Report of a case. Surg Today. 2006;36:474-7.

25. Sandner A, Kösling S, Helmbold P, Winkler M, Bloching MB, Holzhausen HJ. Primary nasal natural killer/T-cell lymphomas: Classification and clinicopathological features. HNO. 2007;55: 93-9.

26. McElroy MK, Read WL, Harmon GS, Weidner N. A unique case of an indolent CD56-positive T-cell lymphoproliferative disorder of the gastrointestinal tract: A lesion potentially misdiagnosed as natural killer/T-cell lymphoma. Ann Diagn Pathol. 2011;15:3705.

27. Ko YH, Cho EY, Kim JE, Lee SS, Huh JR, Chang HK, Yang WI, Kim CW, Kim SW, Ree HJ. NK and NK-like T-cell lymphoma in extranasal sites: A comparative clinicopathological study according to site and EBV status. Histopathology. 2004;44:480-9.

28. Lin YN, Chou JW, Chuang PH, Cheng KS, Peng CY, Chiang IP. Primary small intestinal natural killer/T cell lymphoma mimicking tuberculous peritonitis: Report of a case and review of the literature. Intern Med. 2011;50:515-8.

29. Joo YW, Koh DH, Lee KN, Lee HL, Jun DW, Yoon BC, Choi HS, Lee OY. A case of natural killer like $\mathrm{T}$ cell lymphoma misdiagnosed as Behcet's Enteritis of the terminal ileum. Korean J Gastroenterol. 2011;57:365-9. 